\title{
BETWEEN A ROCK AND A HARD PLACE: RULERS, CITIES, AND "THEIR" JEWS IN AUSTRIA DURING THE PERSECUTIONS OF THE FOURTEENTH CENTURY*
}

\section{Eveline Brugger}

The legal status of Jews in medieval Austria had been defined in the thirteenth century, at a time when the number of Jewish inhabitants and Jewish settlements was growing; a long struggle for the actual rule over the Jews between the Austrian duke and the emperor eventually ended in favor of the duke. The Austrian dukes granted their Jews protection and privileges in exchange for considerable taxation and ducal control of Jewish business. ${ }^{1}$ This arrangement worked smoothly during the thirteenth century, which was mostly a time of peace and prosperity for the Austrian Jewry. However, their dependency on ducal protection left them in a very precarious situation during the fourteenth century, which brought about a steady deterioration of the overall status of the Austrian Jews. ${ }^{2}$

The first persecution of Jews in Austria that went beyond an attack against a single person or family occurred in 1294, in the small Lower Austrian town of Laa an der Thaya. The source from which we learn about this event, an annalistic note written in the Cistercian monastery of Zwettl, established a literary tradition that then occurred repeatedly in the Austrian historiography of the fourteenth century: "Also in the town of Laa, Jews had stolen the body of the Lord, and when they were apprehended burying it in a stable, a few were punished by death, and the

\footnotetext{
* Research for this article was funded by the Austrian Science Fund (FWF), P 21236G18.

1 For a detailed discussion of this development, see the article by Birgit Wiedl in this volume.

2 For the general development of Jewish life in the duchy of Austria during the fourteenth century, see Eveline Brugger, "Von der Ansiedlung bis zur Vertreibung-Juden in Österreich im Mittelalter," in Geschichte der Juden in Österreich, by Eveline Brugger and others (Wien: Ueberreuter, 2006), 123-228, here 169-80, Germania Judaica III 1350-1519, Vol. 3 (Gebietsartikel, Einleitungsartikel, Indices), Ayre Maimon, Mordechai Breuer, and Yacov Guggenheim, ed. (Tübingen: J.C.B. Mohr, 2003), 1977-85.
} 
others fled from the town. In the place where the body of the Lord had been found, however, a chapel was built." ${ }^{3}$

Following the events in Laa in 1294, alleged host desecration became the most frequent reason for outbreaks of anti-Jewish violence in late medieval Austria, ${ }^{4}$ as opposed to other territories in the south of the Empire where accusations of ritual murder were more common. ${ }^{5}$ Several such persecutions followed the one in Laa in quick succession during the first years of the fourteenth century. As in the case of Laa, they were carried out by the citizenry of the towns where the Jews lived, and were not instigated or legitimised by any higher authority, secular or ecclesiastical. Such an action against a group who was under the protection of the duke and so closely linked to him that it technically belonged to his treasure ${ }^{6}$ was a direct challenge to the duke's authority that he could not tolerate. ${ }^{7}$

3 Item in Lâ civitate iudei furati fuerunt corpus Domini, et in stabulo illud sepelientes deprehensi, aliquot morte multati sunt et reliqui a civitate fugerunt. In loco autem ubi corpus Domini inventum fuit, capella constructa est. Eveline Brugger and Birgit Wiedl, Regesten zur Geschichte der Juden in Osterreich im Mittelalter. Vol. 1: Von den Anfängen bis 1338 (Innsbruck-Wien-Bozen: StudienVerlag, 2005) [online: http://www.injoest.ac.at/projekte/ laufend/mittelalterliche_judenurkunden/index.php?lang=EN], 89, nr. 82.

4 Gavin Langmuir, Toward a Definition of Antisemitism (Berkeley-Los Angeles-Oxford: University of California Press, 1990), 120-33; Friedrich Lotter, "Hostienfrevelvorwurf und Blutwunderfälschung bei den Judenverfolgungen von 1298 ('Rintfleisch') und 1336-1338 ('Armleder')," in Fälschungen im Mittelalter 5: Fingierte Briefe. Frömmigkeit und Fälschung. Realienfälschungen (MGH Schriften 33/5, Hannover: Hahnsche Buchhandlung, 1988), 533-83, here 536-48, Miri Rubin, Corpus Christi: The Eucharist in Late Medieval Culture (Cambridge: Cambridge University Press, 1991).

5 Rainer Erb, "Zur Erforschung der europäischen Ritualmordbeschuldigungen" in Die Legende vom Ritualmord. Zur Geschichte der Blutbeschuldigung gegen Juden, Rainer Erb, ed. (Berlin: Metropol-Verlag, 1993), 9-16; Langmuir, Antisemitism, 263-81; Michael Toch, Die Juden im mittelalterlichen Reich (Enzyklopädie deutscher Geschichte 44) (München: Oldenbourg, 2003), 113-15.

6 Friedrich Battenberg, "Des Kaisers Kammerknechte. Gedanken zur rechtlich-sozialen Situation der Juden in Spätmittelalter und Früher Neuzeit," Historische Zeitschrift 245 (1987), 545-99, here 569-70; Brugger, "Ansiedlung," 136-37; Alexander Patschowksy, "Das Rechtsverhältnis der Juden zum deutschen König (9.-14. Jahrhundert). Ein europäischer Vergleich," Zeitschrift der Savigny-Stiftung für Rechtsgeschichte, Germanistische Abteilung 110 (1993), 331-71, here 344-45; Toch, Juden im mittelalterlichen Reich, 48-49.

7 For the political role which his rule over the Austrian Jews played for the duke at the time see Eveline Brugger, "Minem herren dem hertzogen sein juden: Die Beziehung der Habsburger zu 'ihren' Juden im Österreich des 14. Jahrhunderts," in 25. Österreichischer Historikertag, St. Pölten 2008 (St. Pölten: Verlag des Instituts für Niederösterreichische Landeskunde, 2010), 742-49, here 742-43; Eveline Brugger, "Do musten da hin zue den iuden varn - die Rolle(n) jüdischer Geldgeber im spätmittelalterlichen Österreich," in Ein Thema-zwei Perspektiven. Juden und Christen in Mittelalter und Frühneuzeit, Eveline Brugger and Birgit Wiedl, ed. (Innsbruck-Wien-Bozen: StudienVerlag, 2007), 122-38, here 123-26; Klaus Lohrmann, Judenrecht und Judenpolitik im mittelalterlichen Österreich (WienKöln: Böhlau, 1990), 114-22. 
In 1305, an alleged host desecration in the small town of Korneuburg (near Vienna) led to the tumultuous murder of ten Jews, most likely the entire Jewish population of the town, by the citizens. ${ }^{8}$ Since the bloodstained host wafer that had been found on the threshold of a Jew's house was soon said to work miracles, the bishop of Passau ordered a thorough investigation of the case. The Cistercian Ambrose of Heiligenkreuz, whom the bishop of Passau had put in charge of the investigation, complained bitterly about the way the Habsburg Duke Rudolf III interfered with the ongoing interrogation of witnesses. ${ }^{9}$ In his theological treatise Tractatus de hostia mirificata, which was based on the events of Korneuburg although it was written several years later, ${ }^{10}$ Ambrose emphasized that the duke tried to speed up the proceedings and kept the citizens from testifying about the alleged miracles caused by the desecrated host wafer. However, there is no evidence that Duke Rudolf punished the citizens of Korneuburg who had murdered "his" Jews, probably because he didn't want to risk a direct confrontation with the ecclesiastical authorities involved.11

8 From the ample literature on the 1305 persecution of Korneuburg see Germania Judaica II Von 1238 bis zur Mitte des 14. Jahrhunderts, Zvi Avneri, ed. (Tübingen: J.C.B. Mohr 1968), II/1, 450, II/2, 894; Miri Rubin, Gentile Tales. The Narrative Assault on Late Medieval Jews (New Haven-London: Yale University Press, 1999), 57-65; Winfried Stelzer, "Am Beispiel Korneuburg: Der angebliche Hostienfrevel österreichischer Juden von 1305 und seine Quellen," in Österreich im Mittelalter. Bausteine zu einer revidierten Gesamtdarstellung (Studien und Forschungen aus dem Niederösterreichischen Institut für Landeskunde 26), Willibald Rosner, ed. (St. Pölten: Selbstverlag des Niederösterreichischen Instituts für Landeskunde, 1999) 309-48, here 313-14, 328-40; Brugger, “Ansiedlung," 211-16; and Birgit Wiedl, "The Host on the Doorstep: Perpetrators, Victims, and Bystanders in an Alleged Host Desecration in Fourteenth-Century Austria," in Crime and Punishment in the Middle Ages and Early Modern Times. Fundamentals of Medieval and Early Modern Culture 7, Albrecht Classen and Connie L. Scarborough, ed (Berlin-Boston: Walter de Gruyter, 2012), 301-47.

9 Brugger, "Studien und Forschungen aus dem Niederösterreichischen Institut für Landeskunde 38), Anton Eggendorfer and Willibald Rosner, ed. (St. Pölten: Selbstverlag des Niederösterreichischen Instituts für Landeskunde, 2004), 48-49. The notarial account of the interrogation has been preserved in its entirety, and although the questions which the twenty-one witnesses had to answer were mostly focussed on the question whether the host wafer had been consecrated and the alleged miracles, several of the witnesses also gave detailed information on the murder of the Jews. For the most recent edition see Brugger, Wiedl, Regesten 1, 125-42, nr. 133.

10 Stelzer, "Korneuburg," 337-39.

11 For the most recent edition of the passages from Ambrose's treatise concerning the actions of the duke see Brugger, Wiedl, Regesten 1, 144, nr. 135. From the treatise, we also learn that a local priest later confessed that he had staged the whole incident by putting an (unconsecrated) bloodstained wafer on the threshold of the Jewish house. In spite of this confession, the "miraculous host" of Korneuburg remained a center of pilgrimage well into the early modern period. Brugger, "Ansiedlung," 214-15, Stelzer; "Korneuburg," 337. 
A year later, in 1306, a similar persecution in the Lower Austrian town of St. Pölten (also caused by an alleged host desecration) provoked a completely different reaction from Rudolf III. St. Pölten was not under ducal rule, but under the rule of the bishop of Passau, who had failed to protect the Jews against the wrath of the citizens. Rudolf III saw this as a chance to interfere on behalf of "his" Jews in a town that was, technically, not under his jurisdiction, thus emphasising that all the Jews, wherever they lived on Austrian territory, belonged to him, and expanding his authority at the expense of the bishop of Passau. Rudolf resorted to drastic measures to enforce his authority: according to monastic sources, he threatened to destroy the city and rebuild it on ducal land if the citizens didn't pay a fine of 3500 pounds. ${ }^{12}$ From the duke's point of view, this makes sense: the death of "his" Jews had been a financial loss to him, and the citizens had to make up for that loss financially.

The implications of the fact that the Jews played a mostly financial role for the duke were, of course, not lost on the citizens, who tried to use the Jews in their cities as a bargaining chip when they were struggling with the duke over legal or financial matters. If the duke had reason to pander to the citizens' demands, the Jews often ended up on the losing side. The most frequent example was a prohibition against Jews working in certain crafts or holding offices. The inclusion of such prohibitions into a municipal charter was usually the result of the duke's need to acquiesce to the citizens' wishes, often because there were several contenders for the rule over the city in question. ${ }^{13}$

Power struggles between the Austrian duke and the citizenry became particularly important for the Jews during times of persecution. Usually, the actual protection that the duke was able to grant at such times was extremely limited, since he did not have the means to intervene very quickly or simply because it was all over by the time he even learned of the event. During the local, more or less spontaneous persecutions that sprung up in the first decades of the fourteenth century, the only thing the duke could do in these cases was to punish the offenders afterwards. The willingness of the Austrian dukes to protect the Jews and to implement such punishments earned them harsh criticism from the clergy; Duke

12 For the annalistic accounts of the persecution see Brugger, Wiedl, Regesten 1, 154-55, nr. 145; 155, nr. 146. In March 1307, the convent of St. Pölten had to sell three vineyards to co-finance the city's payments to the duke (Brugger, Wiedl, Regesten 1, 160, nr. 152). See also Lohrmann, Judenrecht, 118-20; Brugger, “Ansiedlung," 216.

13 See the article by Birgit Wiedl in this volume. 
Rudolf III was reproachfully dubbed fautor Judeorum (patron of the Jews) by the aforementioned Ambrose von Heiligenkreuz, ${ }^{14}$ an epithet that was later also used for Rudolf's younger brother Duke Albrecht II. ${ }^{15}$

The situation was somewhat different during the first big 'wave' of persecutions that hit the duchy of Austria in 1338. For the first time in the history of Jewish settlement in Austria, an outbreak of anti-Jewish violence went beyond the local scope. The cause was once more an alleged host desecration: on 27 April 1338, a bloodstained host wafer was found in front of a house in Pulkau (Lower Austria) which belonged to the Jew Merchlin, who had been living in Pulkau for at least a decade at this point. ${ }^{16}$ This discovery not only led to the murder of the Jewish population of the town, but also triggered a persecution that spread to other places in Lower Austria and in the neighbouring countries of Bohemia and Moravia. Almost parallel to the catastrophic "Armleder" persecutions that heavily affected the Jewish communities in Southern Germany from $1336-1338,{ }^{17}$ the Pulkau persecution marks the first time in Austria that a local incident caused wide-spread violence against the Jewish population, affecting about 30 towns overall. ${ }^{18}$ This persecution drastically showed

14 In the same text, a narrative about Jews in Vienna stealing a host wafer, which was probably written after Rudolf's death in 1307, Ambrose accused the duke of protecting 'his most beloved Jews' in order to profit from their usury. Brugger, Wiedl, Regesten 1, 156-57, nr. 147; Lohrmann, Wiener Juden, 150-51; Lotter, Hostienfrevelvorwurf, 560-61; Stelzer, "Korneuburg," 332-33.

15 Brugger, "Ansiedlung," 173, 219; Johann Egid Scherer, Die Rechtsverhältnisse der Juden in den deutsch-österreichischen Ländern. Mit einer Einleitung über die Principien der Judengesetzgebung in Europa während des Mittelalters (Beiträge zur Geschichte des Judenrechtes im Mittelalter 1) (Leipzig: Duncker \& Humblot, 1901), 370.

16 Merchlin der Jud ze Pulka, mentioned in a German charter in 1329, is most likely identical with Marquardus iudeus, in front of whose house the bleeding host was found in 1338. Brugger, Wiedl, Regesten 1, 257-58, nr. 303; 334-35, nr. 436.

17 Lotter, "Hostienfrevelvorwurf," 576-79. Although the chronological coincidence with the "Armleder" persecutions that heavily affected many Jewish communities in Southern Germany is striking, there seems to be no immediate connection between them and the Pulkau persecutions. The authorities' suppression of the "Armleder" riots was not motivated by a concern for the Jews, but by the need to put a stop to a movement that was perceived as a dangerous social uprising, even if it sometimes led to the same kind of criticism that the dukes of Austria had to face for protecting their Jews. František Graus, Pest-Geißler-Judenmorde. Das 14. Jahrhundert als Krisenzeit (Veröffentlichungen des Max-Planck-Instituts für Geschichte 86) (Göttingen: Vanderhoeck \& Ruprecht, ${ }^{2} 1987$ ), 295-96; Jörg R. Müller, "Erez gezerah - 'Land of Persecution': Pogroms against the Jews in the regnum Teutonicum from c. 1280 to 1350," in The Jews of Europe in the Middle Ages (Tenth to Fifteenth Centuries) Christoph Cluse, ed. (Turnhout: Brepols, 2004), 245-260, here 254-56.

18 The Hebrew Martyrology from the Nürnberg Memorial book lists Austrian, Bohemian, Moravian, and Carinthian towns and villages; see Siegmund Salfeld, Das Martyrologium 
the limits of the protection the authorities were able to give the Jews. Jewish settlement seems to have come to an end in some small towns and concentrated on the communities in bigger cities that were better protected. ${ }^{19}$

However, the citizens of those bigger cities saw a chance to use the danger the Jews were in to their own advantage. In Vienna, the citizenry forced the Viennese Jewish community to agree to a severe reduction of interest rates on Jewish loans for citizens of Vienna in return for protection. The privilege that Duke Frederick II had granted the Austrian Jews in 1244 had allowed them an interest rate of eight pence per pound per week, even though interest rates had begun to decline since then. ${ }^{20}$ In June 1338, the leaders of the Jewish community issued a charter in Hebrew in which

des Nürnberger Memorbuches (Quellen zur Geschichte der Juden in Deutschland vol. 3) (Berlin: Verlag Leonhard Simion, 1898), 68, 240-41, and Brugger, Wiedl, Regesten 1, 348-49, nr. 455. The ecclesiastical historiography of the time has much information on the topic; see Brugger, Wiedl, Regesten 1, 333-35, nrr. 434-36 and 434-51, nrr. 448-56. Generally Manfred Anselgruber and Herbert Puschnik, Dies trug sich zu anno 1338. Pulkau zur Zeit der Glaubenswirren (Pulkau s.a.); Miri Rubin, Gentile Tales: The Narrative Assault on Late MedievalJews (New Haven-London: Yale University Press, 1999), 65-68 (with several factual errors concerning the general history of the region); GJ II/2, 641, 665-66, 694; Lohrmann, Judenrecht, 145, 155-56, Mitchell B. Merback, Pilgrimage \& Pogrom: Violence, Memory, and Visual Culture at the Host-Miracle Shrines of Germany and Austria (Chicago-London: University of Chicago Press, 2012), 69-80. The number of Jewish victims is unknown; however, since most Jewish settlements in smaller towns only consisted of a few families at most, Miri Rubin's estimate that 150 Jews were killed in Pulkau alone (Rubin, Gentile Tales, $65,68)$ seems highly unlikely.

19 Brugger, "Ansiedlung," 174. The Continuatio Novimontensis, another monastic account of the events, states explicitly that the Jews were killed exceptis his, qui in civitatibus, sicut in Winna et in Nova Civitate sitis in Austria, a ducibus et baronibus sunt protecti ("except those who, in cities like Vienna and Wiener Neustadt situated in Austria, were protected by the dukes and the nobles"); see Brugger, Wiedl, Regesten 1, 344, nr. 449.

20 Jewish business charters indicate that in most cases, this maximum rate was only charged as default interest if the debtor failed to pay his debts at the due date. The actual interest rate was camouflaged by giving only the total amount of the due sum, not the amount of the original loan. Still, the enormous interest rate of eight pence per pound per week, which equals a yearly interest rate of 173.3 percent, was frequently used to denounce Jewish usury - not only by medieval authors, but also by modern anti-Semites. Michael Toch, "Jüdische Geldleihe im Mittelalter," in Geschichte und Kultur der Juden in Bayern, ed. by Manfred Treml and Josef Kirmeier (München-New York-London-Paris: K.G. Saur, 1988), 85-94, here 89-90; Michael Toch, "Geld und Kredit in einer spätmittelalterlichen Landschaft. Zu einem unbeachteten Schuldenregister aus Niederbayern (13291332)," Deutsches Archiv 38 (1982), 499-550, here 514-15; Hans-Jörg Gilomen, "Wucher und Wirtschaft im Mittelalter," Historische Zeitschrift 250 (1990), 265-301, here 294; Klaus Lohrmann, Die Wiener Juden im Mittelalter (Berlin-Wien: Philo, 2000), 68; Markus Wenninger, "Juden und Christen als Geldgeber im hohen und späten Mittelalter," in Die Juden in ihrer mittelalterlichen Umwelt, Alfred Ebenbauer and Klaus Zatloukal, ed. (WienKöln-Weimar: Böhlau, 1991), 280-99, here 283-84. 
they lowered the maximum interest rate for loans given to Viennese citizens to three pence per pound per week. The text of the charter states that the Jews had voluntarily granted the reduction of interest rates to show their gratitude for the help they had received from the citizens in a time of danger, yet one of the rabbis who signed it added the epithet "the most ashamed" to his name, thus clearly expressing his unhappiness. ${ }^{21}$ Dukes Albrecht II and Otto had to agree to the reduction in order to keep the Viennese Jews safe, although every measure that hurt their Jewish subjects economically meant financial losses for the dukes as well. ${ }^{22}$

There are no sources indicating that the dukes punished the citizens of the towns where Jews had been attacked, probably because they were taken by surprise by the scale of the persecutions and afraid of provoking further outbreaks of violence. Duke Albrecht seems to have tried to get help from the church: Pope Benedict XII, whom the duke had informed of the events, promised to charge the bishop of Passau with an investigation which, if the Jews should be found innocent of host desecration, would lead to the punishment of those Christians who had killed the Jews and plundered their houses. ${ }^{23}$ Even though the investigation seems to have been carried out, there are no records of any punishment dealt out by Church authorities. ${ }^{24}$ Like Korneuburg, Pulkau became a pilgrimage site, ${ }^{25}$

21 The Hebrew charter was sewn onto the ducal confirmation; besides, the city of Vienna copied the Hebrew text (and a German translation) into the "Eisenbuch," a chartulary for important municipal documents. Brugger, Wiedl, Regesten 1, 336-38, nr. 439; Lohrmann, Wiener Juden, 71-75.

22 Brugger, Wiedl, Regesten 1, 338; nr. 440; Lohrmann, Judenrecht, 155-56, 178-79. Although both the Jewish and the ducal charters were directed at the citizens of Vienna only, the interest rate of 8 pence subsequently disappeared almost completely. This is, however, part of a bigger development that was limited neither to Jewish loans nor to Austria, since interest rates were generally declining during the fourteenth century. Wenninger, "Juden und Christen als Geldgeber," 290.

23 The text of Albrecht's letter to the pope is unknown; only Benedict's answer to Albrecht and his mandate to the bishop of Passau were preserved in the papal register. Brugger, Wiedl, Regesten 1, 339-41, nrr. 442-43; Heinz Schreckenberg, Die christlichen Adversus-Judaeos-Texte und ihr literarisches und historisches Umfeld (13.-20. Jahrhundert) (Europäische Hochschulschriften, Reihe XXIII Theologie 497) (Frankfurt a. M.-BerlinBern-New York-Paris-Wien: Peter Lang, 1994), 373-74, Shlomo Simonsohn, The Apostolic See and the Jews. Vol. 1: Documents 492-1404, Studies and Texts vol. 94 (Toronto: Pontifical Institute of Medieval Studies, 1988), 371-74, nr. 354-55.

24 The theological treatise that was written on the matter by Frederick, canon of Bamberg Cathedral, indicates that he was involved in the investigation. Anselgruber, Puschnik, Pulkau, 53-65; Brugger, Wiedl, Regesten 1, 49-50, nr. 456; Merback, Pilgrimage \& Pogrom, 76; Rubin, Gentile Tales, 67.

25 Anselgruber, Puschnik, Pulkau, 65-67. The Holy Blood Church in Pulkau still houses a sixteenth-century winged altarpiece decorated with panels depicting the Jewish host 
even though the correspondence between the duke and the pope had mentioned the fact that the "miraculous" bleeding host of Korneuburg had been a fake, and the bishop of Passau had his own doubts about the veracity of the Pulkau host. ${ }^{26}$ Although the dukes were keen on protecting their Jews, they still did nothing to stop the veneration of host wafers allegedly desecrated by Jews; Duke Otto even founded an Augustinian monastery in Korneuburg in 1338 and endowed it with a plot of land 'which had once belonged to the Jews.' ${ }^{27}$

Still, Duke Albrecht II seems to have taken the lesson learned from the events of 1338 to heart, because he was able to protect the Austrian Jews a decade later, when the Black Plague was used as a pretext for huge and wide-spread persecutions in many territories of the Holy Roman Empire. It is important to point out that the big persecutions during the time of the plague, especially during the later stages in 1349, were not carried out spontaneously by fearful or traumatised groups of citizens, but mostly were initiated and organised by municipal authorities or, in several cases, even by the ruler of the territory in question. ${ }^{28}$ The Austrian Jews, however, survived these critical times almost completely unscathed because of strong and efficient ducal protection. There is one single exception, a persecution of Jews in the autumn of 1349 that was carried out by the citizens of Krems, where one of the biggest and most important Jewish communities in Austria was situated. Monastic annals report that the usual accusations of bringing about the plague by poisoning the wells were raised against the Jews of Krems, which caused the citizens to burn most of the Jews in their houses on St. Michael's Day (29 September 1349). Duke Albrecht II, who was dubbed with the aforementioned epithet fautor Iudeorum, on this occasion punished the citizens heavily, both by sending troops to arrest those who had attacked the Jews (several of the arrested citizens were later executed or died in prison) and by collecting hefty fines. ${ }^{29}$

desecration, although the panels are no longer on public display. For photographs, see Rubin, Gentile Tales, 150-51, Merback, Pilgrimage \& Pogrom, plates 7-9.

26 The bishop of Passau gave order to place another, consecrated host wafer behind the "miraculous" Pulkau host to prevent idolatry. Brugger, Wiedl, Regesten 1, 347-48, nr. 453; Rubin, Gentile Tales, 66. There is mention of a priest faking the bleeding host in John of Winterthur's chronicle; see Brugger, Wiedl, Regesten 1, 346-47, nr. 452. It is, however, not fully clear whether the author was referring to Pulkau or to the Korneuburg case. Wolfgang Stefan Koller, "Die Korneuburger Bluthostie. Historische Quellen und Wirkung" (unpublished master's thesis, University of Vienna, 1991), 20-22.

27 Brugger, Wiedl, Regesten 1, 343, nr. 447.

28 Müller, "Erez geserah," 256-57; Toch, Juden im mittelalterlichen Reich, 62-63.

29 Eveline Brugger and Birgit Wiedl, Regesten zur Geschichte der Juden in Österreich im Mittelalter. Vol. 2: 1339-1365 (Innsbruck-Wien-Bozen: StudienVerlag, 2010) [online: http:// 
Even the inhabitants of the neighbouring town of Mautern, which was under the rule of the bishop of Passau, were fined for participating in the persecution-in spite of the bishop's intervention on behalf of his subjects. ${ }^{30}$ In a way reminiscent of Rudolf III's actions against St. Pölten in 1306, Albrecht II was able to use his position as the legal protector of the Austrian Jews in order to intervene in a town that was technically not under his rule. Overall, Albrecht's swift and brutal reaction may have set an example that helped to hold citizens and/or municipal authorities who might have been interested in getting rid of their Jews in check, thus keeping the other Jewish communities in the duchy of Austria safe.

The same was not the case in other territories that are part of today's Austria, where the Jewish inhabitants were affected by the wave of persecutions that often even preceded the actual outbreak of the plague. There are records about persecutions in the territories of the archbishop of Salzburg in 1349, although we know very little about them; the same is true for the vast possessions of the bishop of Bamberg in Carinthia. ${ }^{31}$ In the west of today's Austria, the territories around Lake Constance, which were divided into many small dominions under different rulers, were most heavily affected. Responsibility for the Jewish communities around Lake Constance was divided between the emperor, to whom they paid a part of their taxes, and the cities the Jews lived in, which also got their share in taxation. There was no territorial authority interested in protecting the Jews as there was in the duchy of Austria, which explains the extreme impact of the plague persecutions in these parts. ${ }^{32}$ Little is known about the impact the plague had on the Jews in the country of Tyrol, but there are indications of plague-related persecutions there as well. ${ }^{33}$

www.injoest.ac.at/projekte/laufend/mittelalterliche_judenurkunden/index.php?lang=EN], 97-98, nr. 646-47; Anton Kerschbaumer, Geschichte der Stadt Krems (Krems: Faber, 1885), 284.

30 Hannelore Hruschka, "Die Geschichte der Juden in Krems von den Anfängen bis 1938" (unpublished doctoral thesis, University of Vienna, 1978), 110-12; Scherer, Rechtsverhältnisse, 370.

31 Wilhelm Wadl, Geschichte der Juden in Kärnten im Mittelalter. Mit einem Ausblick bis zum Jahre 1867 (Das Kärntner Landesarchiv, vol. 9) (Klagenfurt: Verlag des Kärntner Landesarchivs, 2009), 166, 173-74; Markus Wenninger, "Zur Geschichte der Juden in Salzburg," in Geschichte Salzburgs Stadt und Land, vol. 1/2: Mittelalter, Heinz Dopsch and Hans Spatzenegger ed. (Salzburg: Pustet, 1983), 747-56, here 748.

32 Karl-Heinz Burmeister, Geschichte der Juden in Stadt und Herrschaft Feldkirch (Schriftenreihe der Rheticus-Gesellschaft, Vol. 1) (Feldkirch: Rheticus-Gesellschaft, 1993), 9; Karl-Heinz Burmeister, "Die Juden in Vorarlberg im Mittelalter," in Aron Tänzer, Die Geschichte der Juden in Hohenems (repr. Bregenz: Verlagsbuchhandlung H. Lingenhöle \& Co., 1982), 807-24, here 816-20.

33 Klaus Brandstätter, "Jüdisches Leben in Tirol im Mittelalter", in Jüdisches Leben im historischen Tirol, vol. 1: Vom Mittelalter bis 1805, ed. by Thomas Albrich (Innsbruck-Wien: 
Throughout the Habsburg countries, the citizenry began to participate more actively in the protection of "their" Jews in the second half of the fourteenth century. The municipal authorities' main interests were financial matters that concerned the city and the question of jurisdiction over the Jews. ${ }^{34}$ There were fewer persecutions of Jews in the second half of the century than there had been in the first half. There is an interesting, if somewhat questionable, record of a persecution in the Habsburg territories of Styria and Carinthia in 1397, which is said to have caused many Jews to flee to Vienna. According to the source, the Austrian duke prevented an outbreak of anti-Jewish violence in the city of Vienna in exchange for a promise by the Jewish refugees to pay him 16.000 marks for their protection. "Also ist Osterreich der Juden verhaissen und gesegnent land" ("thus Austria is the promised and blessed land of the Jews"), the source concludes somewhat indignantly. In the course of the same persecution, which was mostly carried out by members of the nobility who wanted to kill the Jews in order to get rid of their own debts, the Styrian cities of Graz, Radkersburg, and Pettau allegedly refused to surrender their Jews to those who wanted to kill them. ${ }^{35}$ In the same year, Jews in the duchy of Austria were granted a new privilege by Dukes Leopold IV and Wilhelm that renewed their old rights and freed them from extraordinary taxation. ${ }^{36}$ This measure, together with a mention that the privilege had been granted to compensate the Jews for the damage they had suffered, is a strong indication that the persecution of 1397 actually happened, and even if the aforementioned report is likely exaggerated, it is nevertheless a very characteristic example of the Jews being caught between different factions.

Haymonverlag, 2013), pp. 11-134, here pp. 32-34, Gretl Köfler, "Zur Geschichte der Juden in Tirol," Das Fenster 25 (1979/80), 2530-37, here 2530-31; Salfeld, Martyrologium, 82-83, 282-83 (mention of Innsbruck, the Tyrolean capital, as a "blood city" in 1349), Scherer, Rechtsverhältnisse, 576.

34 Birgit Wiedl, "Jews and the City. Parameters of Jewish Urban Life in Late Medieval Austria," in Urban Space in the Middle Ages and the Early Modern Age. Fundamentals of Medieval and Early Modern Culture 4, Albrecht Classen, ed. (Berlin: Walter de Gruyter, 2009), 73-308, here 291-93.

35 Monumenta Germaniae Historica, Deutsche Chroniken VI, Joseph Seemüller, ed. (Hannover: Hahn, 1909), 238; Stephan Laux, “Dem König eine 'ergetzlikhait,' Die Vertreibung der Juden aus der Steiermark (1496/97)", in Jüdisches Leben in der Steiermark. Marginalisierung, Auslöschung, Annäherung, Gerald Lamprecht (Innsbruck-Wien-MünchenBozen: StudienVerlag, 2004), 33-57, here 36; Artur Rosenberg, Beiträge zur Geschichte der Juden in Steiermark (Quellen und Forschungen zur Geschichte der Juden in DeutschÖsterreich, Vol. 6) (Wien-Leipzig: Verlag Wilhelm Braumüller, 1914), 5-6; Scherer, Rechtsverhältnisse, 468-69.

${ }^{36}$ Lohrmann, Judenrecht, 233-34. 
In spite of the decrease in the number of persecutions, the protection the Jews got from the rulers themselves was getting weaker during the second half of the fourteenth century. The economic importance of Jewish moneylenders was dwindling. A significant change in the social standing of the customers of Jewish moneylenders and pawnbrokers can be observed, especially in cities: the municipal elites relied less and less on the services of Jewish financiers, while the percentage of small loans taken up by craftsmen and lower-class citizens went up. ${ }^{37}$ Parallel to this development, the importance of the Christian credit business increased steadily, thus creating growing competition for the Jewish moneylenders and diminishing their importance. ${ }^{38}$ This development caused more and more rulers throughout the Empire to consider the option of resolving their financial problems by seizing Jewish property. In Austria, Dukes Albrecht III and Leopold III started to extort money from rich Jewish businessmen in the 1370s by holding them captive until they paid huge sums as ransom. Sometimes, they would single out a particularly wealthy Jewish financier, like the Viennese banker David Steuss, who is reported to have paid the enormous sum of 50.000 pounds in 1383 to regain his freedom. ${ }^{39}$

The growing number of so-called Tötbriefe ("killing letters"), ducal decrees through which the duke annulled the debts of persons or institutions he wished to favor without any compensation to the Jewish moneylender in question, also indicates clearly that ducal protection of Jewish business was deteriorating. ${ }^{40}$ Sometimes, these "killing letters" were issued because a Jew fled from the Austrian territory-Jews needed the permission of the duke to move to another ruler's territory-but they were also issued for Jews who were still in Austria and who suffered financial losses to the benefit of a party whom the duke wished or needed to favor. ${ }^{41}$ Duke Rudolf IV (1358-1365), who placed great importance on stressing his sole right to rule over the Austrian Jews (up to the point of including it into his famous falsification of imperial privileges for Austria in the so-called

37 Hans-Jörg Gilomen, Juden in den spätmittelalterlichen Städten des Reichs: NormenFakten-Hypothesen. Kleine Schriften des Arye Maimon-Instituts, 11 (Trier: Eigenverlag des Instituts, 2009), 28.

38 Brugger, "Rolle(n) jüdischer Geldgeber," 133; Toch, "Jüdische Geldleihe," 89-90; Wenninger, "Juden und Christen als Geldgeber," 288-89; Wiedl, "Jews and the City," 301.

39 Brugger, "Ansiedlung," 220; Lohrmann, Judenrecht, 216-17.

40 Brugger, Adel und Juden, 108; Lohrmann, Judenrecht, 171-73.

41 Brugger, “Ansiedlung," 145; Lohrmann, Judenrecht, 217-220. 
Privilegium maius), ${ }^{42}$ was especially quick to use them, although he often chose to take over outstanding Jewish debts instead of simply annulling them. ${ }^{43}$

Therefore, while the legal position of the Jews in Austrian towns and cities had not become that much weaker during the fourteenth century, their actual situation was much more precarious at the end of the century than it had been at the beginning. Consequently, the beginning of the fifteenth century marks a period when rulers decided more and more frequently that the Jews were no longer necessary for them at all, and that they could profit financially from confiscating the property of Jewish victims of persecutions. ${ }^{44}$ The fifteenth century became the period of persecutions that were now instigated and carried out by the rulers themselves (albeit occasionally in collaboration with the affected cities), eventually leading to the expulsion of the remaining Jews. ${ }^{45}$

42 Urkundenbuch zur Geschichte der Babenberger in Österreich, vol. 4/1, Heinrich Fichtenau, Erich Zöllner, and Heide Dienst, ed. (Wien: Verlag Adolf Holzhausens Nachfolger, 1968), 151-57, nr. 804; Lohrmann, Judenrecht, 209-10.

43 On the most prominent Jewish victims of this policy, Mosche of Maribor and Häslein of Friesach, see Eveline Brugger, "Loans of the Father: Business Succession in Families of Jewish Moneylenders in Late Medieval Austria," in Generations in Towns. Succession and Success in Pre-Industrial Urban Societies, Finn-Einar Eliassen and Katalin Szende, ed. (Newcastle upon Tyne: Cambridge Scholars Publishing, 2009), 112-29, here 119-21.

44 On the topic of Jewish expulsions in the Empire in general see Markus Wenninger, Man bedarf keiner Juden mehr. Ursachen und Hintergründe ihrer Vertreibung aus den deutschen Reichsstädten im 15. Jahrhundert (Wien-Köln-Graz: Böhlau, 1981). For the Austrian territories see Brugger, "Ansiedlung," 221-27.

45 For the duchy of Austria, the year 1421 marks the end of medieval Jewish settlement. During the years 1420/21, the Austrian Jews were hit by the most catastrophic medieval persecution in the territory of today's Austria. Duke Albrecht V had hundreds of Austrian Jews captured and killed while others reportedly committed suicide to escape forced baptism; the survivors were driven from the country. The Jewish martyrs were commemorated in the "Vienna Gesera," a Yiddish account of the events. See Artur Goldmann, Das Judenbuch der Scheffstrasse zu Wien (1389-1420). (Quellen und Forschungen zur Geschichte der Juden in Deutsch-Österreich, Vol. 1) (Wien-Leipzig: Wilhelm Braumüller 1908), 125-32; GJ III/3, 1986-88; Martha Keil, "Bet haKnesset, Judenschul. Die mittelalterliche Synagoge als Gotteshaus, Amtsraum und Brennpunkt sozialen Lebens," in Wiener Jahrbuch für jüdische Geschichte 4 (1999/2000), 71-89, here 73-74. 